Original Research Paper

\title{
Education in the Field of National Information Security in the Russian Federation and Abroad
}

\author{
${ }^{1,2}$ Alexander A. Galushkin \\ ${ }^{1}$ Department of Humanitarian, Social, Economic and Information-Legal Disciplines, \\ Stolypin International Institute of Informatization and Public Administration, Moscow Region, Russian Federation \\ ${ }^{2}$ Department of Municipal Law, Peoples' Friendship University of Russia, Moscow, Russian Federation
}

Article history

Received: 11-10-2015

Revised: $31-10-2015$

Accepted: 16-12-2015

Email: alexander.galushkin@yandex.ru

\begin{abstract}
In the present article author conducts research of current issues of training and education in the field of national information security in the Russian Federation and abroad in the context of globalization. Author analyzes current legal framework, analyzes opinions of scientists and specialists. Author marks out the place and role of new scientific and educational specialty-Information Law, given an opinion on the relevance of its occurrence. Author notes that each year, with the introduction of new technologies, increased levels of Informatization and computerization, there are now more issues of state (national) and collective information security. Solving these issues is impossible without ensuring an adequate level of training of new professionals, as well as timely retraining of skills of already working employees. This requires further comprehensive work on organization and implementation of specialized educational programs of the new generation. During the research author analyzes opinions of scientists from different countries, representing different scientific schools.
\end{abstract}

Keywords: Information, Security, National, Education, Trainings

\section{Introduction}

In the history of civilization, there have been several information revolutions-transformation of social relations due to the profound changes in the field of information processing.

The first revolution is associated with the invention of writing, which led to a huge qualitative and quantitative leap. There appears a possibility of transmission of knowledge from generation to generation.

The second information revolution, which occurred in the middle of the XVI century, was caused by the invention of printing, which radically changed the industrial society, culture, organization of activities.

The third information revolution, which occurred in the end of XIX century, was due to the invention of electricity, which brought up the telegraph, telephone, radio and allows quick transmission and storage of information of any volume.

The fourth information revolution, which occurred in the 70th of the XX century, is associated with the invention of microprocessor technology and advent of the personal computer.
The right to freedom of information in the form, in which it now exists in international human rights instruments, is a manifestation of the traditional freedoms of thought and expression in the international exchange of information (Avdeev, 2013). Nowadays this right may be associated with many other rights, including protection of human rights of children.

In 2011 and 2013 the Russian Federation has become a State party to two important international treaties on the protection of human rights of childrenConvention on the Civil Aspects of International Child Abduction of 1980 (Abashidze et al., 2015a) and the Convention on Jurisdiction, Applicable Law, Recognition, Enforcement and Co-operation in respect of Parental Responsibility and Measures for the Protection of Children's Rights of October 19, 1996Hague Child Protection Convention of 1996 (Abashidze et al., 2015b).

This is especially important to outline, as in the 90-th of the XX century in Russian Federation, there have been significant changes in the social, economic and cultural spheres. Collapse of the Soviet Union led to many changes in the civil society. 
Foreign products, technologies and services appeared in the country, many of which have never been previously made in the USSR, or the circle of individuals, who used those in the era of the Soviet Union, was severely limited.

It was not an exception for information (including telecommunication) technologies. Personal computers became widely spread, as well as a foreign software for them and also printers, scanners and other related equipment for both civilian and military, as well as dual-use.

Russian Federation, by contrast to other states of the world, rather recently felt the results of the fourth information revolution, associated with the invention and introduction into production of microprocessors and specialized programming, as well as the advent of personal computers and portable information transmission technologies (including protocols).

The introduction of these technologies into mass use, including the discovery of mass user Internet access and access to networks, such as intranets occurred after the collapse of the Soviet Union.

Today Information technology has become part and parcel of many people's daily lives to such an extent that a lot of activities are now either fully carried out online, or done with help of the Internet (Galushkin, 2015).

\section{Materials and Methods}

In the present article author present results of the conducted research, where the research problem was formulated, an empirical base accumulate. Author focused on the research process and drawn the conclusions that reflect the real situation in the best possible way.

\section{Results}

It is obvious, that such volume of research questions fully expedient to regard as a separate scientific specialty, which was created by the referred order.

Recent years were marked by important changes in the field of education in Russian Federation in whole, not only education.

On September 1, 2013 the Federal Law of December 29, 2012 No. 273-FZ "On Education in the Russian Federation" (hereinafter-Law No. 273-FZ) came into force (with the exception of certain provisions). In this case, a number of provisions (in some parts the powers of the authorities of the regional and local level in the field of education) will take effect from the January 01, 2014.

This document was prepared by the Ministry of Education and Science of the Russian Federation in order to systematize and improve legislation in the field of education. It replaced a number of regulations such as the Law of the Russian Federation from the July 10,
1992 No. 3266-1 "On Education” (hereinafter-Law No. 3266-1), Federal Law of August 08, 1996 No. 125-FZ "On Higher and Postgraduate Vocational Education".

Law No. 273-FZ is a comprehensive document, which included general provisions and rules, governing relations in the individual subsystems of education (pre-school, general, secondary vocational and higher education).

Referred Law retained existing basic principles and norms (including the part of the state guarantees for the realization of rights to education, right to choose the educational organization and education in accordance with the inclinations and needs, education in their native language, legal guarantees of accessibility and quality of education and others). The text of the Law No. 273-FZ reflected previous legislation enshrined the principles of public free education in Russia. Thus, state guarantees availability and free access to education, in accordance with the federal state educational standards of preschool, primary general, basic general and secondary general education, secondary vocational education, as well as on a competitive basis a higher education, if this education level is obtained for the first time.

However, Law No. 273-FZ provides a number of innovations, due to the need to modernize the system of education in modern conditions (Consultant Plus, 2015).

In accordance with the law, in the 2013, a number of regulations, governing the issues of education in the field of information security were signed.

Government of the Russian Federation by its Decree from May 24, 2013 No. 437 "On approving the list of professions for which the federal government professional educational institutions implementing educational programs of secondary vocational education in the fields of defense production for Defense Contracts, internal affairs, security, nuclear energy, transport and communications, high-tech industry", in accordance with article 6 of the Federal Law from December 29, 2012 No. 273-FZ "On Education in the Russian Federation" approved the list of professions for which federal governmental professional educational institutions, implementing educational programs of secondary vocational education in the fields of defense production products for the defense contracts, internal affairs, security, nuclear energy, transport and communications, Hightech industry, (GDRF, 2013) and including:

- 090000-Information Security

- 090300-Information Security of Computing, Automation and Telecommunications Systems

- 090303-Information Security of Telecommunications Systems 
- 090305-Information Security of Automated Systems

- 090900 Information Security

- 090905-Organization and Information Security Technology

It is obvious, that in the present conditions, when almost everyone could receive higher education without exception, there is a significant shortage of qualified professionals. This vocational education may be the key to solving many problems.

Nevertheless, we should not forget about the professional retraining and advanced training of personnel.

On December 5, 2013 Ministry of Education and Science of the Russian Federation by the Order No. 1310 "On approval of the development of additional professional programs containing information constituting a state secret and additional professional programs in the field of information security", in accordance with paragraph 8 of Article 76 of the Federal Law from December 29, 2012 No. 273-FL "On Education in the Russian Federation", subsection 2.5.51 of the Regulations on the Ministry of Education and Science of the Russian Federation approved in the agreement with the Federal Security Service of the Russian Federation and the Federal Service for Technical and Export Control of the Russian Federation approved the procedure for additional professional development programs, containing information constituting a state secret and additional professional programs in the field of information security.

Thus, Ministry of Education and Science of the Russian Federation has established rules for the development of additional professional programs, containing information constituting a state secret and additional professional programs in the field of information security, which are mandatory for the institutions of additional professional education, educational institutions of higher education, professional educational organizations, conducting training (research organizations or other legal entities) (OMESRF, 2013).

\section{Discussion}

In Russia and in the world past few decades have been marked by the emergence of a significant number of popular Internet resources (from news sites, entertainment portals, services, share music, movies and other content to chats, forums, social networking, online shopping and so on).

We can assume a global trend to the gradual displacement of the large part of trade and services in the network space (sales and services) remotely using the Internet.

Also, a growing number of media are distributed partially or completely via the Internet. Russian
Federation, as a full member of the contemporary international community is no exception to this rule.

The increasing popularity acquires Internet-based technologies in the Russian Federation. Gradually, our citizens are getting used to buy goods, services through a variety of Internet resources and pay cashless by debit or credit cards. A variety of forums, chat rooms and social networks are getting increasing popularity. Nowadays majority of Russian citizens have an access to the Internet.

With active introduction of information technologies and their application by public authorities the Russian Federation, along with other countries of the developed world, many officials felt threats to the information security, both on the local, state (national) and international level.

Previously it usually was for a number of reasons, first, in the Russian Federation mostly foreign technology are used, at the same time, domestic technologies often have been completely non-competitive and commercially viable and domestic experts, though having extensive background knowledge, often do not have basic practical knowledge and skills, which are required to work with foreign technologies and software.

By virtue of a good basic education, many domestic experts fairly quickly acquired necessary skills and knowledge, sometimes at the expense of self-education, or by studying abroad.

Of course, such approach has the right to life, but more effective and expedient is to organize appropriate specialized training on the territory of the Russian Federation.

It is important to note, that such situation is not only in Russia. For example, Edgar-Nevill D.-Head of Department of Computing at Canterbury Christ Church University in the United Kingdom as well as Chair of the British Computer Society Cybercrime Forensics Specialist Group outlines that since 2000 there has been a clear recognition of the accelerating threats to society posed by those who would exploit computers for crime and the logical progression to cyber-terrorism and cyberwarfare.

In 2002 a committee of UK Members of Parliament highlighted how unprepared the country was to deal with this problem: "We have around 140,000 police officers in the UK. Barely 1000 have been trained to handle digital evidence at the basic level and fewer than 250 of them are currently with Computer Crime Units or have higher-level forensic skills." Since then the capacity to deal with digital crime has improved but the problem has grown alarmingly. In the last decade the author has been working with The College of Policing (formerly named the NPIA) and developed a jointly validated Masters programme for UK law enforcement, intelligence and Government agencies. 
A variety of courses have now been taken by thousands of police officers in this area acting as firstresponders to crime scenes and more specialist High Tech Crime Units (Edgar-Nevill, 2013).

The education system in the Russian Federation had undergone many changes during lust 20 years. Many changes are going nowadays.

The Russian education system must switch from a survival mode to the mode of development. Consequently, the system of education in the present day should function in the mode of development of selfmotion, self-development (Grudtsyna, 2013).

The education of professionals should not be deep theoretical, but has practical orientation. Education, of course, must be carried out according to different levels of training, but based on either high school education or on the higher professional education-bachelor and/or musters degree. A specialized commission should conduct a more detailed discussion.

Professor Spafford G. from the Purdue University (United States) points out that that there are only a few universities that teach a comprehensive curriculum in these topics serves to illustrate the imprecise nature of the field. Many professionals have taken to describing it as "information security" or "information assurance" to distinguish that the focus is not on computers and networks, but on the information they hold and process.

One conclusion .... is that getting good information security education widely implemented may not be simple, given current constraints and traditions within academia (Spafford, 2004). It is hard to argue with this.

Often information security on the national level is closely related to the question of access to the information which is a state secret. Partially this is due to the terrorism threat. Recently, Russian government, understanding this fact, along with the need to regulating such specialized questions of education, developed some acts.

On the 29th of April, 2003 the Ministry of Education of the Russian Federation with the Order No. 1918 "On approval of the Coordination Council of the Russian Ministry on the training of specialists in the field of protection of state secrets and information security" in accordance with the Order of the Ministry of Education of Russia on February 25, 2003 No. 670 "About creation Coordination Council of the Russian Ministry on the training of specialists in the field of protection of state secrets and information security" has approved the provision of the Coordinating Council of the Ministry of Education of the Russian Federation on the training of specialists in the field of protection of state secrets and to identify the objectives, tasks, rights and obligations this Council.

By its nature, the Council is a coordination and advisory body under the Ministry of Education of the
Russian Federation and conducts its activities in accordance with the legislation of the Russian Federation in the field of education, information security and protection of state secrets, decrees and orders of the President of the Russian Federation, decisions and orders of the Government of the Russian Federation, the decisions of the Interdepartmental Commission on Information Security of the Security Council of the Russian Federation and the Interdepartmental Commission for the Protection of State Secrets, normative legal acts of Russian Ministry of Education and the federal executive bodies, the responsibility for the issues of information security and protection of state secrets, as well as other regulatory acts.

The purpose of the Board is to ensure the quality of training and improvement of professional training in the field of protection of state secrets and information security, as well as the following tasks:

- Implementation of the unified state policy in the field of training to meet the requirements of government regulation from the side of the federal executive bodies, responsible for the protection of state secrets and information security

- Organization of the development of legal documents draft, governing the operation of educational institutions of secondary, tertiary, postgraduate and additional professional education in the field of protection of state secrets and information security

- Determination of the order and rules of educational programs of vocational education, containing information constituting a state secret implementation, organization of educational process on them

- Organization of scientific research on the educational methods of production in the field of information security and protection of state secrets under the orders and programs of the Ministry of Education of the Russian Federation, programs of federal executive bodies, the Security Council of the Russian Federation, the Interdepartmental Commission for the Protection of State Secret (OMERF, 2003)

Unfortunately, there is not enough publicly available information, which is not a state secrets or other classified information protected by law, from which it is possible to get detail regarding the activities of the Council.

Author feels important to pay attention to issues of preparation of candidates and doctors of law in the field of Information Law.

On the January 10, 2012 by the Order of the Ministry of Education and Science of the Russian Federation No. 5 "On Amendments to the Nomenclature of specialties of scientific workers, approved by order of 
the Ministry of Education and Science of the Russian Federation of February 25, 2009 No. 59" approved changes to the nomenclature of scientific specialties, which was approved by the Ministry of Education and Science of the Russian Federation on February 25, 2009 by the Order No. 59 and amended by the Ministry of Education and Science of the Russian Federation on the August 11, 2009 by the Order No. 294 and on November 16,2009 by the Order No. 603).

Referred Order supplemented the branch of science "Jurisprudence" by the specialty 12.00.13-"Information Law" through its separation from specialty 12.00.14"Administrative Law, Financial Law, Information Law" (OMESRF, 2012).

Some researchers believe that institutional framework of information security based on the fact that the information falls under the rules of property law, which makes it possible to apply to it the norms of criminal and civil law in its entirety (Chesnokov, 2013). Such approach is questioned by some other researchers. It appears to be reasonable to refer to the source of law on this question.

In accordance with the passport of the scientific workers specialties (PSWS, 2013), formula of the referred specialty is: Content of the specialty 12.00 .13 "Information Law" is the study of the subject and method of legal regulation, sources and state laws, legal institutions and legal relations in the information environment, development of proposals on the improvement of legislation and law enforcement practice in information area.

Directions of research in this specialty are: Legal regime of information; information environment, information technology and information systems as objects of legal regulation; formation of legal framework of the information society, information of legal culture, electronic government and electronic segment of the economy (electronic economic activity); realization and protection of human rights in the information sphere; legal and information security, information protection and information infrastructure; prevention of disclosure of violations and liability for violations in the information sphere.

In the field of the research are such questions as:

- Theoretical study of the subject, the system and structure of information law

- Information, information environment, information resources, information technology, information systems and information activities as objects of the legal regulation. Information space. Turnover of information and information sphere. Information environment of global computer networks, including the Internet

- Theory and practice of human rights and freedoms in the information sphere realization. Legal basis for the formation and development of information society in the Russian Federation. State information policy. Global Information Society

- State management in the sphere of information. Legal regulation of the information support in the activity of public authority ("e-government", "edemocracy" and "e-justice"). Information bases of the social control

- Information services. Providing of state and municipal services in the electronic form

- Boundaries and limits of state regulation and selfregulation in the field of information. Legal regulation of the cross-border communication and the problem of jurisdiction of various states in the information sphere

- Place of the Information Law in the system of Russian law. Problems of Information Law relationship with other branches of the Russian law

- Science of Information Law: Especially development and regularities of formation in Russia and foreign countries.

- Problems of methodology in Information Law

- Information and legal provisions and their implementation

- Sources of Information Law. Status of information legislation, problems and prospects of its development. Problems of systematization and codification of information legislation. Place and role of the model laws in the information legislation

- Principles of Information Law

- Information relationships: Objects, subjects, content. Types of information relations

- Legal status of the subjects of Information Law. Informational intermediary as the subject of information law

- Legal regimes of information objects. Legal basis for the access to information resources

- Right to information. Legal regime of protection, implementation and protection of information rights (rights of subjects of information relations). Legal regime of information. Legal regime of open and publicly available information. Legal protection of public information and social networks. Legal regulations of information, dissemination of which is restricted or prohibited. Confidentiality of information. Types of secrets. Legal regime of personal and family secrets, privacy. Legal regime of the state, official, professional, commercial and other secrets protected by law. Legal protection of the secret source of information

- Legal regulation of organization and use of means of communication, global computer networks, including the Internet. Legal basis for the use of information technology (Information) and information infrastructure. Legal regulation of 
information relations, emerging in the cloud using information technology

- Legal basis of information and a common information space, as well as the use of automated information systems

- Legal regulation of relations in the field of information security of individuals, society and the state. International problems of legal regulation of information security

- Legal regulation of information relations in the field of personal data protection. Personal data as the Institute for the Protection of the right to privacy and identification of persons in the socio-economic, political and cultural life of the society

- Legal regulation of information relations in the sphere of mass media. Features of the legal status of the Media

- Legal regulation of information relations in the field of archives and libraries

- Legal regulation of information relations in the field of document and workflow in electronic form. Legal regulation of the digital signature use

- Legal protection of intellectual property in the information sphere

- Legal regulation of information relations, emerging in the economic sphere (in the sphere of economic activity, information economy, e-commerce). Legal regulation of information relations in the field of advertising

- Responsibility for the violation of information legislation. Problems of legal liability in the information law

- Problems of international cooperation in the legal regulation and the development of the information environment, including in the framework of regional forms of cooperation (CIS, Customs Union, CSTO, BRICS and others)

- Organizational and legal problems of international information security. Challenges and threats in the information sphere, information warfare, information weapons

- Problems of international law implementation into the national information legislation of the Russian Federation. Problems of the foreign experience of legal regulation of information relations use

In lust years even judicial system is facing changes in the information field. For example in Russian Federation the state automated system of Russian Federation "Justice" was created and introduced (Sangadzhiev et al., 2013).

Introduction of such systems require computer special knowledge from judges and stuff.

\section{Conclusion}

In general, there was a pronounced trend in attention to issues of training, specializing in information security, including national. This is due to a pronounced shortage of qualified personnel and a significant increase in the rate of the information technologies introduction.

Due to the big interest a lot of educational programs were created in many educational institutions in Russia.

Such educational programs are of interest not only in Russia, they are of interest globally. For example Professor McCrie R.D. from the John Jay College of Criminal Justice (United States) points out that John Jay College has offered a degree in security management since 1972. The program now includes three degrees (AS, BS and MS in Protection Management), two nonmatriculate certificate programs and a facility to provide education and training to the community at large, the Security Management Institute. ... Since the blow to the city and the nation on $9 / 11 / 01$, courses have been revised to include more emphasis on counter-terrorism, cybercrime and emergency response and mitigation" (McCrie, 2005).

Cyberterrorism and Cyberespionage problem is a critical problem that requires well educated specialized professionals to counteract these challenges. However this is only one side of the problem. One more side is the appropriate daily work of information systems, especially governmental (because most of them store critical information).

In Russian Federation, at the end of 2013, the Register of federal government information systems contained 323 entries. Of these, the commissioning of 4 new federal government information systems was planned in 2014. Obviously, for the full operation of effective public information systems, as well as many other systems require competent legal regulation, but not less important is having appropriately trained sufficient amount of reliable information technology professionals.

Every year, with the introduction of new technologies, increasing levels of information spread and computerization, there are more issues of state (national) and collective information security. Solving these problems is impossible without ensuring an adequate level of new professionals training, as well as timely retraining and improving of skills of currently working specialists.

It is important to outline that education in this field is of interest in different countries. For example Scientific group from the Christ Church University (Great Britain) "looks at some of the innovative academic partnerships that have been developed to address the issue of Cybercrime Forensic 
Investigation Training and Specialist Education in the UK and illustrate the impact that they have on European requirements as outlined by the Bologna Agreement and Europol initiatives" (Stephens and Induruwa, 2007).

There should be conducted further comprehensive research on the organization and implementation of specialized educational programs of the new generation and legal regulation of such questions.

\section{Acknowledgement}

Author thanks reviewers for given recommendations, editorial board and stuff of the journal for the well-done work and the sensitive approach.

\section{Funding Information}

Research is conducted with the financial aid of the grant of the President of the Russian Federation MK4283.2015.6.

\section{Author's Contributions}

Presented article is prepared solely by the author, is a unique author research.

\section{Ethics}

This article is original and has not been published elsewhere.

\section{References}

Abashidze, A.K., D.A., Gugunskiy, A.K. Koneva, M.A. Simonova and A. Solntsev et al., 2015a. Current problems of interstate cooperation of Russian federation for the protection of children in case of disputes between parents living in different states. Asian Social Sci., 11: 337-337.

DOI: $10.5539 /$ ass.v1 $1 \mathrm{n} 14 \mathrm{p} 337$

Abashidze, A.K., D.A., Gugunskiy, A.K. Koneva, A.M. Solntsev and N.A. Grigorieva, 2015b. Current issues of application of Hague child protection convention of 1996 on national level. Mediterranean J. Social Sci., 6: 289-298.

DOI: $10.5901 /$ mjss.2015.v6n4s4p289

Avdeev, M.Y., 2013. Privacy and the right to information: The realities of Russia and foreign experience. Pravovaya Initsiativa.

Chesnokov, N.A., 2013. The legal framework of information security in modern conditions. Pravovaya Initsiativa.

Consultant Plus, 2015. Legal News. Special issue. "Commentary to the Federal Law No. 273-FL of December 29, 2012 "On Education in the Russian Federation". Consultant Plus.
Edgar-Nevill, D., 2013. ECENTRE-Education as a defensive weapon in the war against cybercrime. Proceedings of the 12th European Conference on Information Warfare and Security, (IWS' 13), pp: 54-54.

Galushkin, A., 2015. Internet in modern Russia: History of development, place and role. Asian Social Sci., 11: 305-310. DOI: 10.5539/ass.v1 $1 \mathrm{n} 18 \mathrm{p} 305$

Grudtsyna, L.Y., 2013. Innovative processes in modern Russian education. Pravovaya Initsiativa.

GDRF, 2013. On approving the list of professions for which the federal government professional educational institutions implementing educational programs of secondary vocational education in the fields of defense production for defense contracts, internal affairs, security, nuclear energy, transport and communications, high-tech industry. GDRF, Consultant Plus.

McCrie, R.D., 2005. Serving security: A history of security management education at John Jay College of criminal justice. J. Security Educ., 1: 83-93.

DOI: 10.1300/J460v01n01_08

OMERF, 2003. On approval of the coordination council of the Russian ministry on the training of specialists in the field of protection of state secrets and information security. OMERF, Consultant Plus.

OMESRF, 2012. On amendments to the nomenclature of scientific specialties approved by the ministry of education and science of the Russian federation of February 25, 2009 No. 59. OMESRF, Consultant Plus.

OMESRF, 2013. On approval of the additional professional development programs containing information constituting a state secret and additional professional programs in the field of information security. OMESRF, Consultant Plus.

PSWS, 2013. According to the nomenclature of specialties 12.00.13-"Information Law". bulletin of the stolypin international institute of informatization and public administration. PSWS.

Sangadzhiev, B.V., N.N. Marchuk and A.A. Galushkin, 2013. Courts of general jurisdiction in Russian federation as an instrument of human rights and freedoms protection. World Applied Sci. J., 26: 688-691. DOI: 10.5829/idosi.wasj.2013.26.05.1736

Spafford, G., 2004. What *is* Information Security? Proceedings of the 35th SIGCSE technical symposium on Computer Science Education, Mar. 03-07, Norfolk, VA, USA, pp: 342-342. DOI: $10.1145 / 971300.971304$

Stephens, P. and A. Induruwa, 2007. Cybercrime investigation training and specialist education for the European Union. Proceedings of the 2nd International Annual Workshop on Digital Forensics and Incident Analysis, Aug. 27-28, IEEE Xplore Press, Samos, pp: 28-37.

DOI: 10.1109/WDFIA.2007.4299370 